\title{
First report of avocado tree wilt by Pythium sp. amazonianum in Mexico
}

\author{
Yisa M. Ochoa Fuentes ${ }^{1}$, Anselmo Hernández Pérez ${ }^{1}$, Juan C. Delgado \\ Ortiz ${ }^{1}$, Mariana Beltrán Beache², Luis M. Tapia Vargas³, Omegar Hernández \\ Bautista $^{2}$, and Ernesto Cerna Chávez ${ }^{1}$ \\ 'Universidad Autónoma Agraria Antonio Narro, Departamento de Parasitología. Buenavista, Saltillo, \\ Coahuila, México CP 25315. \\ ${ }^{2}$ CULTA S.A. de C.V Bulevar Luis Echeverría Álvarez No. 1700, Colonia Altavista, CP. 89880, CD. Mante, \\ Tamaulipas, México. \\ ${ }^{3}$ Instituto Nacional de Investigaciones Forestales Agrícolas y Pecuarias, Campo Experimental Uruapan. \\ Avenida. Latinoamericana No. 1101 Colonia Revolución CP. 60500, Uruapan, Michoacán, México.
}

\begin{abstract}
Yisa M. Ochoa Fuentes, A. Hernández Pérez, J.C. Delgado Ortiz, M. Beltran Beache, L.M. Tapia Vargas, O. Hernández Bautista, and E. Cerna Chavez. 2018. First report of avocado tree wilt by Pythium sp. amazonianum in Mexico. Cien. Inv. Agr. 45(3): 301-305. In August and September 2014, different avocado orchards (Persea americana Mill. Var. Hass) were sampled in four municipalities (Tancítaro, Uruapan, San Juan Nuevo Parangaricutiro and Peribán) of the "Franja aguacatera" in Michoacan State, Mexico. Samples were collected from avocado trees showing symptoms of the "Tristeza del aguacate" disease. Strains of Pythium sp. were obtained consistently from symptomatic tissue isolated in the selective medium V8®Agar-PARPH. Morphological identification was made through taxonomic keys, and molecular identification was obtained by sequencing Internal Transcribed Spacer (ITS) gene. Koch's postulates were corroborated by pathogenicity tests carried out on $P$. americana seedlings with six true leaves, identifying the strain of $P$. sp. amazonianum as the causal agent of the "Tristeza del aguacate" disease. This is the first report that associates the "Tristeza del aguacate" with $P$. sp. amazonianum in Michoacan, Mexico.
\end{abstract}

Key words: Avocado, Michoacan, oomycete, Pythium, pathogenicity.

\section{Introduction}

Global avocado production is approximately 4,700,000 tons, and Mexico is the largest producer in the world, with more than 175,000 ha; Michoacan State represents most of the planted

Received Nov 22, 2017. Accepted Oct 30, 2018. Corresponding author: jabaly1@yahoo.com surface area with more than 127,000 ha and 10 ton/ha yields. In the state of Michoacan, the region known "Franja aguacatera" has an area of $7,752 \mathrm{~km}^{2}$, which represents $13 \%$ of the total state territory. The "Franja aguacatera" is located in the neovolcanic axis region, which has a forest ecosystem characterized by moderate, humid and subhumid weather, with temperatures from $8{ }^{\circ} \mathrm{C}$ to $21^{\circ} \mathrm{C}$ and annual rainfall between 
1,200 and 1,600 mm (SAGARPA, 2017). Avocado production is affected by a wide range of diseases that cause low yields, malformations in the fruits and even the death of trees; such diseases are caused by different phytopathogens, such as Sphaceloma perseae (scabies), Colletotrichum gloeosporioides (anthracnose) and Phytophthora cinnamomi ("Tristeza del aguacate"). Species of the genera Phytophthora have the greatest economic impact on root rot, leaf and branch wilt and tree death (Davison and Ribeiro, 1996; Pérez, 2008). P. cinnamomi has traditionally been considered the only pathogen related to these symptoms; however, some authors reported new species of pathogens associated with this symptomatology, such as Cylindrocladium parasiticum, Cylindrocarpon liriodendri, Nectria liriodendra and Ilyonectria macrodidyma (Dann et al., 2011; Vitale et al., 2012), as well as Phytopythium vexans isolated from the roots of avocado trees in the Canary Islands, which showed more severe pathogenicity than Phytophthora cinnamomi (Rodríguez et al., 2014). Therefore, the objective of this research was to confirm the species and pathogenicity of Pythium sp. involved as a causative agent of wilt in the avocado orchards of Michoacan, Mexico.

\section{Materials and methods}

\section{Isolation}

From August to September 2014, root samples were collected from avocado trees (Persea americana Mill. Hass var.) that showed typical symptoms of avocado wilting disease (Tristeza del aguacate); the sampled trees had necrotic and brittle roots, yellow leaves and progressive descending mortality. Root samples of infected trees were collected from 40 avocado groves located within the "Franja Aguacatera" area in Uruapan, Peribán, Tancítaro and San Juan Nuevo Parangaricutiro, all belonging to the state of Michoacan, Mexico. The isolation procedure began by eliminating excess soil from the roots with water and making longitudinal cuts no longer than $0.5 \mathrm{~cm}$ each; only dark brown brittle roots were taken from the infection's leading edge. The root cuttings were disinfected with $3 \%$ sodium hypochlorite for $3 \mathrm{~min}$, followed by three washes with sterile distilled water, before being seeded in Petri plates with PARPH selective medium (pimaricin $10 \mu \mathrm{g} \mathrm{mL}^{-1}$, ampicillin $250 \mu \mathrm{g} \mathrm{mL}^{-1}$, rifampicin $10 \mu \mathrm{g} \mathrm{mL}^{-1}$, PCNB 100 $\mu \mathrm{g} \mathrm{mL} \mathrm{m}^{-1}$ and hymexazol $\left.50 \mu \mathrm{g} \mathrm{mL}^{-1}\right)$ according to Davison and Ribeiro (1996). PARPH is the standard selective medium for oomycetes. The Petri plates were incubated during four days at $28^{\circ} \mathrm{C}$. Pure isolates were obtained by transferring 0.5 -cm-diameter discs with mycelia to Petri plates with $\mathrm{V}^{\circledR}$-Agar media.

\section{Identification}

Colonies of pure isolates were identified at the genus level based on taxonomic keys proposed by De Cock and Lévesque (2004) and Bala et al. (2010). Molecular identification was based on ITS-PCR. DNA was extracted from pure and identified isolates using $0.2 \mathrm{~g}$ of mycelia, according to the method of Doyle and Doyle (1990). PCR amplification of the ITS (internal transcript region) was performed with the primers ITS1 (5' - TCCGTAGGTGAACCTGCGG-3') and ITS4 (5'- TCCTCCGCTTATTGATATGC-3'). The PCR amplification conditions were as follows: 1 cycle of initial denaturation at $94{ }^{\circ} \mathrm{C}$ for 5 min, 30 cycles of denaturation at $95{ }^{\circ} \mathrm{C}$ for 10 seconds, 30 cycles of alignment at $57{ }^{\circ} \mathrm{C}$ for 30 seconds, 30 cycles of extension at $72{ }^{\circ} \mathrm{C}$ for $2 \mathrm{~min}$ and 1 cycle of final extension at 72 ${ }^{\circ} \mathrm{C}$ for 5 min (Ochoa-Fuentes et al., 2012). The PCR-amplified products were visualized through electrophoresis in a $2 \%$ agarose gel stained with GelRed $\left(G e n S c r i p t^{\circledR}\right)$. The PCR products were sequenced in both directions. Sequences were compared with the NCBI gene bank database (National Center for Biotechnology Information) (www.ncbi.nlm.nih.gov). 


\section{Pathogenicity tests}

Pathogenicity tests using six-leaf-stage avocado seedlings were based on the inoculation techniques described by Van den Berg et al. (2007) and Engelbrecht and Berg (2013). Control plants were treated with sterile distilled water, and a positive control inoculated with $P$. cinnamomi was also included. All inoculated treatments were replicated three times. The inoculum was prepared with $500 \mathrm{mg}$ of mycelia fractioned by forced stirring for $5 \mathrm{~min}$ in $150 \mathrm{~mL}$ of sterile distilled water. Aliquots of $50 \mathrm{~mL}$ were transferred to sterilized glass flasks with $100 \mathrm{~mL}$ of sterile distilled water. These flasks were used as inoculum. The avocado seedlings for evaluation were obtained from a certified vivarium of the National Institute of Agricultural and Livestock Forestry Research (NIFAP-CEU). Root seedlings were washed with sterile distilled water to remove residues from the substrate. Plant roots were placed in the flasks containing the inoculum (mycelia solution), using one plant per flask. All plants in flasks were kept at $23{ }^{\circ} \mathrm{C}$ in a bioclimatic chamber with a $14 / 10 \mathrm{~h} \mathrm{light/}$ darkness period. Observations were recorded daily for 30 days to detect symptoms that could be expressed by the phytopathogen evaluated in the avocado seedlings.
Finally, the inoculated pathogens were reisolated from necrotic roots using the previously described methodology; replicated tests were conducted to confirm the isolates' identity.

\section{Results and discussion}

From the purification of the strains, 20 isolates were obtained that coincided with the morphology of P. cinnamomi; however, 10 isolates did not coincide with the characteristics of $P$. cinnamomi. The isolates were identified from the above colonies by locating hyaline colonies with aerial, coenocytic mycelium, oogonia with antheridia, and spherical and globular sporangia, confirming the reports of De Cock and Lévesque (2004) and Bala et al. (2010) (Figure 1).

The resulting sequence exhibited $97 \%$ homology with the strain of Pythium. sp. amazonianum (Gene bank access number: EU003445). The isolated strains were deposited in the microorganism collection of the National Center for Genetic Resources, which is part of the National Institute of Forestry, Agriculture and Livestock, with the registration number 1006 and in the world

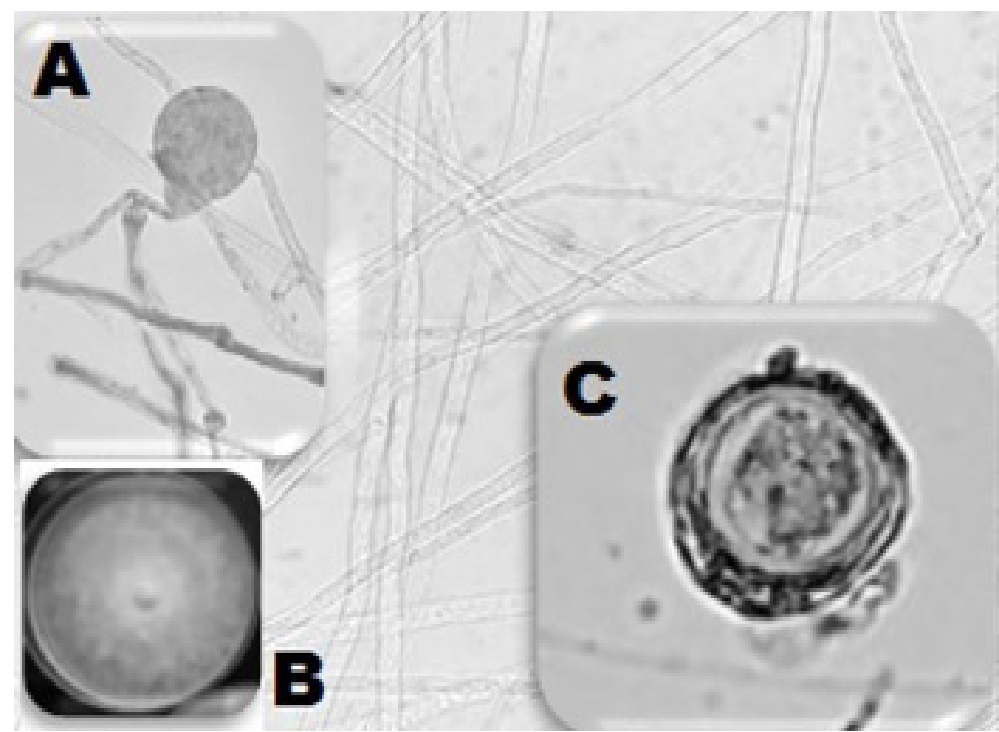

Figure 1. Growth and structures of P. sp. amazonianum, A) sporangium, B) growth in PDA culture medium and C) oogonium. 

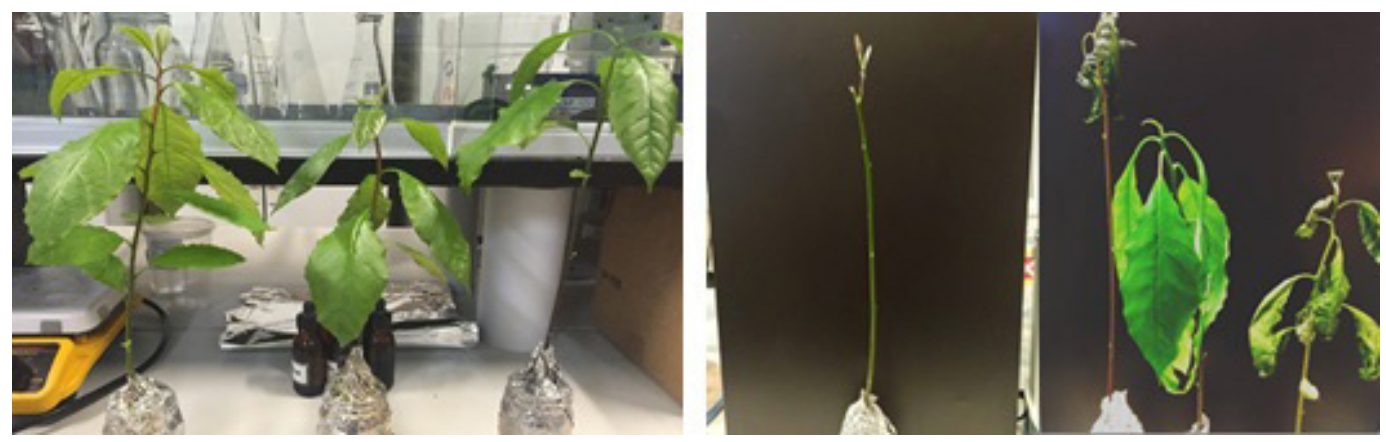

Figure 2. Photographs of avocado plants inoculated with sterile distilled water (left) and plants inoculated with $P$. $s p$. Amazonianum with symptoms of the disease "Tristeza del aguacate" (right).

federation of culture collections (CM-CNRG) with registration number CM-CNRG 409. In the pathogenicity tests, after the first $24 \mathrm{~h}$ from artificial inoculation of the isolates, all the plants showed apical decay (Figure 2). One repetition showed declining and total defoliation in $48 \mathrm{~h}$. At the end of the test (six days), the defoliated stem was turgid and had axillary buds. The root system showed more necrosis, yellowing in the aerial parts of the plant and more brittle roots than our check test inoculated with P. cinnamomi, while the check test inoculated with sterile water did not show any decline or any other symptom of the disease known as avocado wilt or "Tristeza del aguacate".
Symptoms from $P$. sp. amazonianum plant pathogens are similar to the symptoms reported by Téliz and Mora (2007) from P. cinnamomi oomycete and $P$. vexans isolated from the roots of avocado trees in the Canary Islands (Rodríguez et al., 2014). P. sp. amazonianum has been reported in isolates from South African moderate-climate fruit (apple) and citrus trees (Spies et al., 2011), and the same author suggests that the tested pathogen (P. sp. amazonianum) should be considered a new species of the genus Pythium, within K-clade, B-group, Subclade III, as indicated by the morphological differences between the observed structures and the phylogenetic analysis. This is the first report of avocado wilt caused by P. sp. amazonianum in avocado orchards of Michoacan, Mexico.

\section{Resumen}

Yisa M. Ochoa Fuentes, A. Hernández Pérez, J.C. Delgado Ortiz, M. Beltran Beache, L.M. Tapia Vargas, O. Hernández Bautista, y E. Cerna Chavez. 2018. Primer reporte del marchitamiento del aguacatero por Pythium sp. amazonianum en México. Cien. Inv. Agr. 45(3): 301-305. En los meses de agosto y septiembre del 2014 se muestrearon diferentes huertas de aguacate (Persea americana Mill. Var. Hass) en cuatro municipios (Tancítaro, Uruapan, San Juan Nuevo Parangaricutiro y Peribán) de la "Franja aguacatera" en el estado de Michoacán, México. Las muestras se recolectaron de árboles de aguacate que mostraban síntomas de la enfermedad "Tristeza del aguacate". Se obtuvieron cepas de Pythium sp. consistentemente de tejido sintomático, aisladas en medio selectivo V8®-Agar-PARPH. La identificación morfológica se realizó mediante claves taxonómicas y la identificación molecular se obtuvo a través de ITS-PCR. Los postulados de Koch se corroboraron mediante pruebas de patogenicidad llevadas a cabo en plántulas de $P$. americana con seis hojas verdaderas, identificando la cepa de $P$. sp. amazonianum como agente causal de la "Tristeza del aguacate". Este es el primer reporte que asocia la "Tristeza del aguacate" con P. sp. amazonianum en Michoacán, México.

Palabras clave: Aguacate, Michoacán, oomiceto, patogenicidad, pythium. 


\section{References}

Bala, K., G. Robideau, C.A. Levesque, A. Cock, Z. Abad, A.M. Lodhi, S. Shahzad, A. Ghaffar, and M. Coffey. 2010. Phytopythium Abad, de Cock, Bala, Robideau, Lodhi \& Lévesque, gen. nov. and Phytopythium sindhum Lodhi, Shahzad \& Lévesque, sp. nov. Persoonia - Molecular Phylogeny and Evolution of Fungi. 24. 137.

Dann, E., L. Forsberg, A. kooke, K. Pegg, R. Shivas, and Y. Tan. 2011. The "Cylindro" complex of avocado root pathogens. In Memories of the VII World Avocado Congress. Cairns Australia. p 1-12.

Davison, E., and O. Ribeiro, 1996. Phytophthora Diseases Worldwite. American Phytopathological Society Press, Minnesota. pp. 269-280.

De Cock, A.W.A.M., and C.A. Lévesque. 2004. New species of Pythium and Phytophthora. Studies in Mycology 50:481-487.

Doyle, J., and J.L. Doyle. 1990. Isolation of plant DNA from fresh tissue. Focus 12:13-15.

Engelbrecht, J., and N. Berg, 2013. Expression of defence-related genes against Phytophthora cinnamomi in five avocado rootstocks. South African Journal of Science 109:1-8.

Ochoa-Fuentes, Y.M., E. Cerna, Gallegos, G. Landeros, J. Delgado, J.C. Hernández, S. Rodríguez, and Raúl. Olalde, V. 2012. Identificación de especies de Fusarium en semilla de ajo en Aguascalientes, México. Revista mexicana de micología 36:27-32.

Pérez, R.M. 2008. Significant Avocado Diseases Caused by Fungi and Oomycetes. The Europe- an Journal of Plant Science and Biotechnology, 2(1):1-24.

Rodríguez, P.C., A. Rodríguez, and F. Silverio. 2014. Patogenicidad en aguacate de Aislados Locales de Especies de Phytophthora y Phytopythium. Primera descripción de Phytophthora niederhauserii como Patógeno del Aguacate. XVII Congreso de la Sociedad Española de Fitopatología. Lleida, España, octubre 7-10, p. 130.

SAGARPA (2017). Secretaria de Agricultura Ganadería desarrollo Rural Pesca y Alimentación. Disponible en: https:/www.gob.mx/sagarpa.

Spies, C.F.J., M. Mazzola, W.J. Botha, M. Van der Rijst, L. Mostert, and A. McLeod. 2011. Oogonial biometry and phylogenetic analyses of the Pythium vexans species group from woody agricultural hosts in South Africa reveal distinct groups within this taxon. Fungal Biology 115:157-168.

Téliz, D., and A. Mora. 2007. El aguacate y su manejo integrado. Segunda edición. Editorial Mundi Prensa. pp: 192-202.

Van den Berg, N., D.K. Berger, I. Hein, P. Birch, M.J. Wingfield, and A. Viljoen. 2007. Tolerance in banana to Fusarium wilt is associated with early up-regulation of cell wall-strengthening genes in the roots. Molecular Plant Pathology 8:333-341.

Vitale, A., D. Aiello, V. Guarnaccia, G. Perrone, G. Stea, G. Polizzi. 2012. First Report of Root Rot Caused by Ilyonectria (= Neonectria) macrodidyma on Avocado (Persea americana) in Italy. Journal of Phytopathology 160:156-159. 